УДК $615.322+547.913$

DOI: 10.18101/2306-1995-2019-3-20-28

\title{
КОМПОНЕНТНЫЙ СОСТАВ ЭФИРНЫХ МАСЕЛ ДРЕВЕСНОЙ ЗЕЛЕНИ ABIESSIBIRICA И PINUSSYLVESTRIS, ПРОИЗРАСТАЮЩИХ В РЕСПУБЛИКЕ БУРЯТИЯ
}

\section{(C) Эрдынеева Светлана Аркадьевна}

аспирант,

Байкальский институт природопользования СО РАН

Россия, 670047, г. Улан-Удэ, ул. Сахьяновой, 8

E-mail: esssa198013@gmail.com

\section{(C) Ширеторова Валентина Германовна}

кандидат технических наук, старший научный сотрудник, Байкальский институт природопользования СО РАН

Россия, 670047, г. Улан-Удэ, ул. Сахьяновой, 8

тел.: (3012) 43-49-97

E-mail: vshiretorova@rambler.ru

\section{(C) Раднаева Лариса Доржиевна}

доктор химических наук, профессор, заведующая лабораторией,

Байкальский институт природопользования СО РАН

Россия, 670047, г. Улан-Удэ, ул. Сахьяновой, 8

тел.: (3012) 43-49-97

E-mail: radld@mail.ru

заведующая,

кафедра фармации

Бурятский государственный университет им. Д. Банзарова

Россия, 670002, г. Улан-Удэ, ул. Октябрьская, 36а

тел: 8(3012) 44-55-03

E-mail: radld@mail.ru

В результате проведенного исследования из древесной зелени Abies sibirica и Pinus sylvestris, произрастающих на территории Республики Бурятия, методом гидродистилляции выделены эфирные масла (ЭМ), выход которых составил соответственно 4,5-4,6\% и 1,1-1,2\% в пересчете на абсолютно сухое сырье. Компонентный состав эфирного масла был исследован методом хромато-масс-спектрометрии на газовом хроматографе Agilent Packard HР6890 N с квадрупольным масс-спектрометром (НР MSD 5973) в качестве детектора. Доминирующими компонентами эфирных масел для Abies sibirica являются борнилацетат (31,82-37,57\%) и камфен (19,65-19,97\%), для Pinus sylvestris - $\alpha$-пинен $\quad(25,78-32,34 \%)$, лимонен+ $\beta$-фелландрен $(7,58-11,40 \%)$ и 3 -карен $(1,72-14,46 \%)$. Более $90 \%$ эфирных масел составляют компоненты, относящиеся к группе монотерпеноидов, обладающих широким спектром активности в отношении болезнетворных микроорганизмов, что обусловливает перспективность применения данных ЭМ в качестве как самостоятельных лекарственных средств, так и компонентов лекарственных препаратов.

Ключевые слова: древесная зелень, Abiessibirica, Pinussylvestris, эфирное масло, гидродистилляция, газо-хромато-масс-спектрометрия, терпеноиды, борнилацетат,

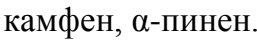


С. А. Эрдынеева, В. Г. Ширеторова, Л. Д. Раднаева. Компонентный состав эфирных масел древесной зелени Abies sibirica и Pinus sylvestris, произрастающих в Республике Бурятия

Для цитирования

Эрдынеева С. А., Ширеторова В. Г., Раднаева Л. Д. Компонентный состав эфирных масел древесной зелени Abies sibirica и Pinus sylvestris, произрастающих в Республике Бурятия // Вестник Бурятского государственного университета. Медицина и фармация. 2019. Вып. 3. С. 20-28.

Одним из путей комплексного рационального использования возобновляемого природного сырья является переработка отходов хвойных пород для получения эфирных масел и целого ряда других продуктов. Эфирные масла, продуцируемые хвойными деревьями, обладают высокими бактерицидными свойствами, играют важную роль в очищении воздуха от болезнетворных микроорганизмов, в охране здоровья человека [1]. В составе древостоев Республики Бурятия, занимающих площадь в 29 140,3 тыс. га, что составляет 83\% всей её территории, хвойные породы составляют 89,4\% [2].

Соединения группы терпенов, входящие в состав ЭМ из хвойных пород деревьев, благодаря своим уникальным фармакологическим свойствам широко распространены в лечении различных болезней. Особенно успешно они используются при лечении ожогов, ран и гнойно-воспалительных процессов, стимулируют неспецифический иммунный ответ, нормализуют гемодинамику пораженной области и активизируют процессы регенерации тканей $[3,4]$. Установлено, что терпеновые соединения могут проявлять обезболивающее, противовоспалительное, ранозаживляющее, антимикробное, антивирусное, антигистаминное, иммуномодулирующее, противоопухолевое, спазмолитическое, успокаивающее действие $[4,5]$. Также эфирные масла и экстракты, получаемые из хвойных деревьев, широко используются в курортной медицине в качестве продукции для принятия ванн [6]. Лечебное действие таких ванн связано с выраженным раздражающим действием на кожу ароматических веществ в сочетании с минеральными солями и температурным режимом.

Преимуществами использования ЭМ в лечебно-профилактических целях являются безопасность и удобство применения, возможность использования всеми возрастными группами. Физиологичное введение путем вдыхания с воздухом способствует возможности непосредственного антисептического и противовоспалительного действия ЭМ на слизистую оболочку респираторного тракта [7].

ЭМ путем разрушения цитоплазматической мембраны патогенных микроорганизмов, а также угнетения их аэробного дыхания оказывают противомикробное действие, которое не снижается со временем и не вызывает развитие резистентности $[7,8]$. В настоящее время установлено, что ЭМ усиливают проникновение антибиотиков через клеточные мембраны организма человека и тем самым дают возможность снизить дозы препаратов при тяжелых заболеваниях [9]. Противоинфекционная активность ЭМ сочетается с их практически полной безвредностью для организма человека, что принципиально отличает их от современных антибактериальных препаратов.

Наибольшее распространение из хвойных эфирных масел получило пихтовое масло, которое входит в Государственный реестр лекарственных средств РФ [10] и является лекарственным средством, относящимся к группе местнораздражающих средств растительного происхождения. При наружном применении оказывает противовоспалительное, обезболивающее и местнораздражающее дей- 
ствие. ЭМ обусловливает и широкий спектр фармакологической активности почек сосны - также официнального средства [11]. Почки сосны используют в медицинской практике в виде отвара, который обладает отхаркивающим, дезинфицирующим, противовирусным, антимикробным, мочегонным и желчегонным действием. Фитонциды пихты убивают коклюшную палочку, сосновые фитонциды губительны для палочки Коха и для кишечной палочки [12].

Известно, что химический состав эфирных масел весьма вариабелен даже в пределах одного вида растений и зависит от места их произрастания, климатических условий, стадии вегетации, технологии выделения масла и от других факторов [13, 14]. Анализ литературных данных показал отсутствие данных по компонентному составу эфирных масел пихты сибирской и сосны обыкновенной, произрастающих в Республике Бурятия, для территории которой характерен резко континентальный климат с большими годовыми и суточными колебаниями температуры воздуха и неравномерными распределением атмосферных осадков по сезонам года.

Цель работы: выделение ЭМ из древесной зелени пихты сибирской (Abies sibirica) и сосны обыкновенной (Pinus sylvestris), произрастающих на территории Бурятии, и определение его компонентного состава методом газохромато-масс-спектрометрии.

\section{Экспериментальная часть}

Образцы древесной зелени Abies sibirica и Pinus sylvestris собирали в июле и сентябре 2015 г. в условиях естественного произрастания. Места и даты сбора проб представлены в таблице 1.

Сбор образцов хвои на территории Республики Бурятия (2015 г.)

Таблий 1

\begin{tabular}{|c|c|c|c|}
\hline \multirow[b]{2}{*}{ № } & \multirow{2}{*}{$\begin{array}{c}\text { Место сбора, географические ко- } \\
\text { ординаты и высота над уровнем } \\
\text { моря (м) }\end{array}$} & \multicolumn{2}{|c|}{ Дата сбора образцов хвои } \\
\hline & & Abies sibirica & Pinus sylvestris \\
\hline & & & \\
\hline 2 & $\begin{array}{l}\text { Иволгинский район, хребет Улан- } \\
\text { Бургасы, } 30 \text { км от г. Улан-Удэ, N } \\
52^{\circ} 50^{\prime} 50^{\prime \prime}, \text { Е } 109^{\circ} 03^{\prime} 40^{\prime \prime}, \mathrm{h}-1290 \\
\text { м } \\
\text { Кабанский район, побережье оз. } \\
\text { Байкал, окрестности пос. Манту- } \\
\text { риха, N 5146'40", Е 10558'51", h } \\
\text {-461 м }\end{array}$ & 18 июля & 10 сентября \\
\hline
\end{tabular}

Горный хребет Улан-Бургасы расположен в центральной Бурятии, формирует восточный борт Байкальской котловины. В большей части хребта преобладает лесной пояс. Климат резко континентальный, с большими амплитудными колебаниями годовой и суточной температуры. Горный рельеф данной местности снижает интенсивность техногенного загрязнения ближайшего 
С. А. Эрдынеева, В. Г. Ширеторова, Л. Д. Раднаева. Компонентный состав эфирных масел древесной зелени Abies sibirica и Pinus sylvestris, произрастающих в Республике Бурятия

источника промышленного загрязнения - г. Улан-Удэ, расположенного в межгорных впадинах и котловинах.

Поселение Мантуриха расположено на берегу Байкала, вблизи устья реки Мантурихи в 12 км к северо-востоку от города Бабушкин. Благодаря расположению на берегу Байкала здесь относительно мягкая зима (температуры от -5 до $\left.-25^{\circ} \mathrm{C}\right)$. Лето прохладное, с большим количеством осадков. Удаленность данного участка от источников промышленного загрязнения позволяет считать данную территорию экологически благополучной.

Древесную зелень по ГОСТ 21769-84 [15] равными долями отбирали с 20 деревьев разного возраста с разных сторон кроны на высоте до 2-2,5 м, после чего проба усреднялась методом квартования. Древесная зелень представляла собой верхушки побегов длиной 15-30 см, наибольший диаметр веточек в нижнем отрубе не превышал 7-8 мм. Массовая доля хвои составляла 80-85\%. Эфирное масло получали методом гидродистилляции измельченного свежего сырья в лабораторной установке с насадкой Клевенджера. Компонентный состав эфирного масла исследовали методом хромато-масс-спектрометрии на газовом хроматографе Agilent Packard HP6890 N с квадрупольным массспектрометром (HP MSD 5973), в качестве детектора использовалась 30метровая кварцевая колонка HP-5 MSD с внутренним диаметром 0,25 мм. Процентный состав эфирного масла вычисляли по площадям газохроматографических пиков без использования корректирующих коэффициентов. Качественный анализ был основан на сравнении рассчитанных значений линейных индексов удерживания, времен удерживания, полных массспектров с библиотекой хромато-масс-спектрометрических данных летучих веществ растительного происхождения. Вычисление линейных индексов удерживания J выполняли в соответствии с [16]. Количественный анализ выполняли методом внутренней нормировки по площадям пиков без использования корректирующих коэффициентов.

\section{Обсуждение результатов}

Полученные эфирные масла представляют собой бесцветные или светложелтого цвета прозрачные подвижные жидкости со специфическим запахом. Выход эфирного масла представлен в таблице 2.

Таблица 2

Выход эфирного масла

\begin{tabular}{|l|l|l|l|l|}
\hline \multirow{2}{*}{ Показатель } & \multicolumn{2}{|c|}{ Abies sibirica } & \multicolumn{2}{c|}{ Pinus sylvestris } \\
\cline { 1 - 5 } & $\begin{array}{l}\text { Улан- } \\
\text { Бургасы }\end{array}$ & Мантуриха & $\begin{array}{l}\text { Улан- } \\
\text { Бургасы }\end{array}$ & Мантуриха \\
\hline Влажность сырья, \% & 54,1 & 51,2 & 49,0 & 52,6 \\
\hline $\begin{array}{l}\text { Выход масла в пересче- } \\
\text { те на абсолютно сухое } \\
\text { сырье (\%) }\end{array}$ & 4,64 & 4,52 & 1,24 & 1,08 \\
\hline
\end{tabular}


Выход эфирного масла из образцов пихты значительно выше (в 3,5-4 раза), чем из образцов сосны обыкновенной. Также можно отметить более высокий выход масла для образцов, собранных на хребте Улан-Бургасы, что, возможно, обусловлено высокогорным характером местности.

Методом газо-хромато-масс-спектрометрии в пихтовом эфирном масле обнаружено 23 (Улан-Бургасы) и 34 (Мантуриха) компонента, из них идентифицированы 100\%; в сосновом эфирном масле обнаружено 50 (Улан-Бургасы) и 55 (Мантуриха) компонентов, из них идентифицировано 47-48, что составляет 99,5-99,7\%.

Результаты хромато-масс-спектрометрического анализа компонентного состава полученных эфирных масел представлены в таблице 3 (приведены компоненты, содержание которых составило более $0,5 \%$ ).

Таблица 3

Компонентный состав ЭМ древесной зелени Abies sibirica и Pinus sylvestris

\begin{tabular}{|c|c|c|c|c|c|}
\hline \multirow{3}{*}{ Компонент } & \multirow{3}{*}{$\mathrm{J}$} & \multicolumn{2}{|c|}{ Abies sibirica } & \multicolumn{2}{|c|}{ Pinus sylvestris } \\
\hline & & $\begin{array}{l}\text { Улан- } \\
\text { Бургасы }\end{array}$ & $\begin{array}{l}\text { Манту- } \\
\text { риха }\end{array}$ & $\begin{array}{l}\text { Улан- } \\
\text { Бургасы }\end{array}$ & $\begin{array}{l}\text { Манту- } \\
\text { риха }\end{array}$ \\
\hline & & \multicolumn{4}{|c|}{$\begin{array}{l}\text { содержание компонентов в процентах } \\
\text { от цельного масла * }\end{array}$} \\
\hline 1 & 2 & 3 & 4 & 5 & 6 \\
\hline толуен & 762 & 2,22 & 2,06 & 2,06 & 1,93 \\
\hline сантен & 884 & 2,05 & 2,65 & - & - \\
\hline трициклен & 921 & 2,23 & 2,14 & 0,81 & 0,74 \\
\hline$\alpha$-пинен & 932 & 7,26 & 8,41 & 25,78 & 32,34 \\
\hline камфен & 947 & 19,97 & 19,65 & 3,53 & 3,25 \\
\hline$\beta$-пинен & 975 & 2,3 & 1,96 & 7,06 & 3,83 \\
\hline$\beta$-мирцен & 991 & 0,70 & 0,54 & 1,40 & 5,53 \\
\hline$\alpha$-фелландрен & 1004 & 0,08 & 0,06 & 0,07 & 0,10 \\
\hline 3-карен & 1010 & 9,91 & 5,10 & 14,46 & 1,72 \\
\hline $\begin{array}{ll}\text { Лимонен } & + \\
\text { фелландрен }\end{array} \quad \beta-$ & 1028 & 8,97 & 8,17 & 7,58 & 11,40 \\
\hline транс- $\beta$-оцимен & 1048 & - & - & 0,39 & 1,34 \\
\hline терпинолен & 1088 & 1,21 & 0,81 & 1,72 & 0,40 \\
\hline борнеол & 1166 & 6,23 & 4,12 & - & 0,09 \\
\hline борнилацетат & 1287 & 31,82 & 37,57 & 1,7 & 4,13 \\
\hline$\beta$-кубебен & 1392 & - & - & 1,09 & 0,99 \\
\hline лонгифиллен & 1408 & 0,48 & 0,67 & - & 0,12 \\
\hline кариофиллен & 1422 & 1,50 & 2,04 & 1,49 & 2,35 \\
\hline гумулен & 1456 & 0,73 & 1,04 & 0,26 & 0,43 \\
\hline
\end{tabular}


С. А. Эрдынеева, В. Г. Ширеторова, Л. Д. Раднаева. Компонентный состав эфирных масел древесной зелени Abies sibirica и Pinus sylvestris, произрастающих в Республике Бурятия

\begin{tabular}{|l|l|l|l|l|l|}
\hline$\gamma$-мууролен & 1480 & - & - & 0,75 & 0,79 \\
\hline гермакрен Д & 1484 & - & - & 2,64 & 2,87 \\
\hline$\beta$-селинен & 1488 & - & - & 0,53 & 0,48 \\
\hline$\gamma$-аморфен & 1496 & - & 0,11 & 0,72 & 0,49 \\
\hline бициклогермакрен & 1500 & - & - & 0,96 & 1,39 \\
\hline$\alpha$-мууролен & 1502 & - & 0,06 & 1,24 & 1,32 \\
\hline$\beta$-бисаболен & 1511 & 0,46 & 0,57 & - & 0,09 \\
\hline$\gamma$-кадинен & 1517 & - & 0,15 & 3,11 & 2,64 \\
\hline$\Delta$ - кадинен & 1527 & - & 0,09 & 8,50 & 8,49 \\
\hline тац - кадинол & 1643 & - & - & 2,92 & - \\
\hline Т-муурол & 1644 & - & - & - & 3,05 \\
\hline$\alpha$-кадинол & 1658 & - & - & 2,96 & 3,37 \\
\hline Примечание: & & & & & \\
\hline
\end{tabular}

Примечание: * — компоненты даны в порядке увеличения времени удерживания; «—- компонент не обнаружен.

Как видно из таблицы 3 , в ЭМ пихты наибольшими по содержанию компонентами являются борнилацетат $(31,82-37,57 \%)$ и камфен $(19,65-19,97 \%)$, а содержание $\alpha$-пинена не превышает $8 \%$. В литературе имеются данные, что борнилацетат и камфен обладают антиоксидантной активностью, подавляют рост инфекций, вирусов, обладают мочегонным, возбуждающим и тонизирующим действием [7].

В образцах ЭМ сосны обыкновенной доминирующими компонентами являются $\alpha$-пинен $(25,78-32,34 \%)$, лимонен+ $\beta$-фелландрен $(7,58-11,40 \%), 3$ карен $(1,72-14,46 \%)$. Известно [8], что $\alpha-$ пинен обладает такими свойствами, как противомикробное, гипотензивные, антиноцицептивные, противовоспалительные, анксиолитические, а также может рассматриваться в качестве потенциального противоопухолевого лекарственного средства.

Более 90\% компонентов эфирного масла сосны и пихты относятся к группе монотерпеноидов, в том числе кислородсодержащих (38-41\%) для пихты и (4-5\%) для сосны. Монотерпеновые углеводороды эфирных масел малотоксичны и обладают широким спектром активности в отношении как человека, так и бо-лезнетворных микроорганизмов [17]. Кислородсодержащие терпеноиды являются ценным сырьем для синтеза медицинской камфоры [18]. 


\section{Выводы}

В результате проведенного исследования выделены эфирные масла из древесной зелени Abies sibirica и Pinus sylvestris, произрастающих на территории Республики Бурятия, выход составил 4,5-4,6 и 1,1-1,2\% в пересчете на абсолютно сухое сырье. Методом газо-хромато-масс-спектрометрии установлен компонентный состав ЭМ: доминирующими компонентами пихтового ЭМ являются борнилацетат (31,82-37,57\%) и камфен $(19,65-19,97 \%)$, соснового ЭМ - $\alpha$-пинен $(25,78-32,34 \%)$, лимонен+ $\beta$-фелландрен $(7,58-11,40 \%)$, 3 карен (1,72-14,46\%). Более 90\% компонентов ЭМ древесной зелени сосны и пихты относятся к группе монотерпеноидов, обладающих широким спектром активности в отношении болезнетворных микроорганизмов, что обусловливает перспективность применения данных ЭМ в качестве как самостоятельных лекарственных средств, так и компонентов лекарственных препаратов.

Исследование выполнено в рамках государственного задания БИП СО РАН.

Литература

1. Воздействие эфирных масел Сибирского региона на условно-патогенные микроорганизмы / Е. Г. Струкова, А. А. Ефремов, А. А. Гонтова, Л. С. Соколова // Химия растительного сырья. 2009. № 4. С. 57-62.

2. Официальный информационный интернет-портал администрации Республики Бурятия [Электронный ресурс]. Режим доступа: https://egovburyatia.ru/mpr/activities/reports_and_reports/gosudarstvennyy-doklad.php, свободный.

3. Шутова А. Г., Спиридович Е. В., Курченко В. П. Биологически активные вещества: эфирные масла растений семейства Рinaceae // Сохранение, изучение и использование биоразнообразия мировой флоры / под ред. В. В. Титка, В. Н. Решетникова. Минск: Беларус. Навука, 2012. С. 292-297.

4. Солдатченко С. С., Кащенко Г. Ф., Головкин В. А. Полная книга по ароматерапии. Профилактика и лечение заболеваний эфирными маслами. Симферополь: Таврида, 2005. $480 \mathrm{c}$.

5. Ефремов Е. А., Назиров Р. А., Ефремов А. А. Концентрирование летучих фитонцидов лесного воздуха хвойных в жидкие среды // Вестник ВГУ. Серия: Химия. Биология. Фармация. 2014. № 2. С. 17-21.

6. Современные бальнеологические средства: формы выпуска и особенности состава / Б. Б. Сысуев, С. Б. Евсеева, А. С. Кайсинова, Т. И. Ледовская // Курортная медицина. 2018. № 2. C. $95-100$.

7. Зайцева С. В., Застрожина А. К., Бельская Е. А. Место ароматерапии в лечении и профилактике острых респираторных заболеваний // Трудный пациент. 2015. Т. 13. № 1-2. С. 48-54.

8. Тихомиров А. А., Ярош А. М. Особенности использования эфирных масел в лечебно-профилактических целях // Фитотерапия. 2008. № 1. С. 18-21.

9. Профилактика респираторных заболеваний летучими растительными веществами: информационное письмо РПК / В. В. Николаевский, А. А. Тихомиров, А. Е. Еременко, М. И. Говорун // Иммунология и аллергология. Киев, 1989.

10. Государственный реестр лекарственных средств РФ [Электронный ресурс]. Режим доступа: https://www.rlsnet.ru/tn_index_id_5543.htm, свободный.

11. Фармакопея РФ. Т. 1. Т. 2. Т. 3. [Электронный ресурс]. Режим доступа: http://femb.ru/feml, свободный.

12. Токин Б. П. Фитонциды, их роль в природе. Л.: Изд-во ЛГУ, 1957. 129 с. 
С. А. Эрдынеева, В. Г. Ширеторова, Л. Д. Раднаева. Компонентный состав эфирных масел древесной зелени Abies sibirica и Pinus sylvestris, произрастающих в Республике Бурятия

13. Методы контроля качества эфирных масел / Н. В. Сегуру, И. П. Рудакова, В. В. Вандышев, И. А. Самылина // Фармация. 2005. № 3. С. 3-5.

14. Лобанов В. В., Степень Р. А. Влияние биоценотических факторов на содержание и состав пихтового масла // Хвойные бореальные зоны. Химическая технология переработки. 2004. № 2. С. 4-8.

15. ГОСТ 21769-84. Зелень древесная. Технические условия. Взамен ГОСТ 2176976; Введ. 01.01.1985; Дата последнего издания: 28.06.1984.

16. Ткачев А. В. Исследование летучих веществ растений. Новосибирск, 2008. 969 с.

17. Кинтя П. К., Фадеев Ю. М., Акимов Ю. А. Терпеноиды растений. Кишинев: Штиинца, 1990. $151 \mathrm{c.}$

18. Рудаков Г. А. Химия и технология камфоры. М.: Лесн. пром-сть, 1976. 208 с.

\section{COMPOSITION OF WOODY GREENS ESSENTIAL OILS \\ ABIESSIBIRICA AND PINUSSYLVESTRIS, \\ NATIVE TO THE REPUBLIC OF BURYATIA}

\section{Svetlana A. Erdneyeva}

Graduate Student,

Baikal Institute of Nature Management SB RAS

8, Sakhyanova st., Ulan-Ude, 670047, Russia

Email: esssa198013@gmail.com

\section{Valentina G. Shiretorova}

Candidate of Technical Sciences, Senior Researcher

Baikal Institute of Nature Management SB RAS

8, Sakhyanova st., Ulan-Ude, 670047, Russia

Tel .: +7(3012) 434997

E-mail: vshiretorova@rambler.ru

\section{Larisa D. Radnaeva}

Doctor of Chemical Sciences, Professor, Head of Laboratory,

Baikal Institute of Nature Management SB RAS

8, Sakhyanova st., Ulan-Ude, 670047, Russia

Tel.: +7(3012)434997

E-mail: radld@mail.ru

Head of the Department of Pharmacy

Buryat State University named after D. Banzarova

36a Oktyabrskaya st., Ulan-Ude, 670002, Russia

Tel: +7(3012) 445503

E-mail: radld@mail.ru

As a result of the study, from the woody greenery of Abies sibirica and Pinus sylvestris, growing in the Republic of Buryatia, essential oils (EO) were isolated by hydrodistillation, the yield of which was $4.54 .6 \%$ and $1.11 .2 \%$, respectively, calculated on absolutely dry raw materials. The composition of the essential oil was studied by gas chromatography-mass spectrometry on an Agilent Packard HP6890 N gas chromatograph with a quadrupole mass spectrometer (HP MSD 5973) as a detector. The dominant components of essential oils for Abies sibirica are bornyl acetate (31.8237.57\%) and camphene (19.6519.97\%), for Pinus sylvestris $\alpha$-pinene (25.7832.34\%), limonene $+\beta$-fellandren (7, 
$5811.40 \%)$ and 3-Karen (1.7214.46\%). More than 90\% of essential oils are constituents belonging to the group of monoterpenoids, which have a wide spectrum of activity against pathogens, which makes it possible to use these EMs as independent drugs or as components of drugs.

Keywords: woody greens, Abiessibirica, Pinussylvestris, essential oil, hydrodistillation, gas chromatography-mass spectrometry, terpenoids, bornyl acetate, camphene, $\alpha$-pinene. 